University of Nebraska - Lincoln

DigitalCommons@University of Nebraska - Lincoln

\title{
INCREASED LAMB PRODUCTION WITH RAMS EXPOSED TO SHORT DAYLENGTHS DURING THE NONBREEDING SEASON
}

B. D. Schanbacher USDA-ARS

Follow this and additional works at: https://digitalcommons.unl.edu/usdaarsfacpub

Part of the Agricultural Science Commons

Schanbacher, B. D., "INCREASED LAMB PRODUCTION WITH RAMS EXPOSED TO SHORT DAYLENGTHS DURING THE NONBREEDING SEASON" (1979). Publications from USDA-ARS / UNL Faculty. 756. https://digitalcommons.unl.edu/usdaarsfacpub/756

This Article is brought to you for free and open access by the U.S. Department of Agriculture: Agricultural Research Service, Lincoln, Nebraska at DigitalCommons@University of Nebraska - Lincoln. It has been accepted for inclusion in Publications from USDA-ARS / UNL Faculty by an authorized administrator of DigitalCommons@University of Nebraska - Lincoln. 


\title{
INCREASED LAMB PRODUCTION WITH RAMS EXPOSED TO SHORT DAYLENGTHS DURING THE NONBREEDING SEASON ${ }^{1}$
}

\author{
B. D. Schanbacher
}

\author{
U. S. Department of Agriculture 2,3 \\ Clay Center, NE 68933
}

\begin{abstract}
Summary
Exposure of rams during the nonbreeding season (anestrous period) to short daylengths will initiate a new sexual cycle characterized by testicular growth, increased mating activity and improved semen quality. Lambing results accumulated from 300 potential matings indicate that rams exposed to artificial photoperiods of $8 \mathrm{hr}$ light and $16 \mathrm{hr}$ darkness for 10 weeks (referred to as rams on short-days) are more fertile than control rams maintained under the relatively long days of spring. When five control rams were penned individually with 30 ewes synchronized with progestogen and PMSG, $67 \%$ of the ewes were mated. Eightynine percent of the ewes were mated with rams on short-days. Expressed as a percentage of the total ewes exposed per ram, 32\% lambed from control matings; whereas, $67 \%$ lambed following exposure to rams on short-days. Combined with a higher number of lambs born per ewe lambing, rams on short-days sired 2.5 times more lambs than did control rams. Results of this study show that the ram contributes significantly to the fertility of single-sire matings and that lamb production can be increased substantially by experimental manipulation of photoperiod. Exposure of both rams and ewes to artificial photoperiods may be a
\end{abstract}

\footnotetext{
${ }^{1}$ The author gratefully acknowledges Mr. Brad Knapp and Mr. Wayne Hinerman for helping with the statistical analyses and cooperation of the Nebraska Agr. Exp. Sta., Univ. of Nebraska, Lincoln.

${ }^{2}$ Roman L. Hruska U. S. Meat Animal Research Center, Agricultural Research, Science and Education Administration.

${ }^{3}$ Mention of a trade name, proprietary product or specific equipment does not constitute a guarantee or warranty by the USDA and does not imply its approval to the exclusion of other products that may also be suitable.
}

useful management tool to distribute the lamb crop to predetermined, specified times of the year.

(Key Words: Photoperiod, Rams, Reproduction, Fertility, Nonbreeding Season.)

\section{Introduction}

Several investigators have pointed out the relationship between decreasing photoperiod or "short-days" and enhanced reproductive activity in rams. Sexual activity peaks in autumn when daylengths are decreasing (Marshall, 1937; Yeates, 1947; Ortavant et al., 1964; Schanbacher and Lunstra, 1976). Exposure of both rams and ewes to artificial photoperiods has clearly demonstrated that this environmental cue is the primary factor that synchronizes reproductive function in breeding flocks (Ortavant, 1977). Decreases in daylength or "short-days" affects the hypothalamic-pituitarytesticular axis in rams as follows: 1) both synthesis and release of $\mathrm{LH}$ and FSH are stimulated (Pelletier and Ortavant, 1964; Pelletier and Ortavant 1975; Lincoln and Peet, 1977; Lincoln et al., 1977; Schanbacher and Ford, 1979); 2) testosterone production and spermatogenesis are enhanced (Ortavant, 1956; Schanbacher and Ford, 1979); and 3) sexual aggressiveness and mating behavior are improved (Lees, 1965; Schanbacher and Lunstra, 1976; Lincoln and Davidson, 1977). The breeding season for rams, therefore, coincides with the short days of autumn; however, exposure of rams to artificial photoperiods makes it possible to stimulate optimum breeding conditions at other times of the year.

More intense management of sheep production with emphasis on lambing throughout the year has renewed our interest in assessing seasonal changes in ram fertility. The develop27

JOURNAL OF ANIMAL SCIENCE, Vol. 49, No. 4, 1979 
seasonal anestrus in ewes (e.g., the use of breeds with extended breeding seasons and (or) the induction of estrus and ovulation by photoperiod manipulation and hormone therapy) requires that rams of high fertility be available at all times of the year. Because considerable evidence is available which indicates poor breeding performance by rams during the nonbreeding season (Dutt, 1960; Lees, 1965), it seems important to critically assess the extent of seasonal infertility in rams and determine whether their reproductive performance can be improved experimentally. The following study was conducted to determine the fertility of rams that had been exposed to short daylengths during the nonbreeding season.

\section{Materials and Methods}

Ten mature Suffolk rams from the US Meat Animal Research Center ram flock with previous breeding experience were used in the following study. These rams had acceptable libido scores during the previous breeding season and were of proven fertility. The experiment began in late February after these 10 rams were randomly assigned to one of two treatment groups. Rams in group I $(n=5)$ served as controls and were maintained outside under ambient conditions of temperature and photoperiod. Rams in group II $(n=5)$ were maintained in a closed building under artificial lighting and exposed to short daylengths (8 hr light and 16 hr darkness). Although temperature for control rams was not static, it changed little during the study (13 to $22 \mathrm{C}$ ). Rams were exposed to either natural or short daylengths for 10 weeks before breeding (February 28 to May 9) and for an additional 3 weeks during breeding (May 9 to May 30).

Scrotal circumference was monitored at weekly intervals during the first 10 weeks of treatment to insure that short daylengths were influential on testicular size. Two semen samples were collected from each ram at the beginning of the study and again just before breeding. Semen samples were collected by electroejaculation and data for semen quality are presented.

Three-hundred Finnish Landrace crossbred ewes that had lambed in February were used to assess differences in ram fertility. The 300 ewes were randomly assigned to 10 units so that information could be obtained from single-sire matings. To insure that a high percentage of ewes would mate and conceive, each ewe was induced to estrus by inserting a progestogen pessary (Searle Synchro-mate; $20 \mathrm{mg}$ of flurogestone acetate) for 14 days, then injecting intramuscularly $500 \mathrm{IU}$ of pregnant mare serum gonadotropin (PMSG, Organon, Inc.) at the time of pessary removal. A second injection of PMSG was given to all ewes 14 days after the first injection (Robinson, 1950; Schanbacher, 1978).

Control and rams on short-days were penned individually with a specified group of ewes for approximately $16 \mathrm{hr}$ per day (May 9 to May 30 ), thus rams were allowed to remain on treatment throughout the breeding period. All rams were removed from breeding pens at approximately $1400 \mathrm{hr}$ and placed back in the breeding pens at approximately $2200 \mathrm{hr}$ so that rams on short-days were exposed to a maximum of $8 \mathrm{hr}$ of light per day ( $\sim 0600 \mathrm{hr}$ to $1400 \mathrm{hr}$ ). Marking harnesses on the rams allowed mating activity to be recorded on a daily basis. Previous experiments have shown that a high percentage of ewes treated with progestogen and PMSG show estrus; however, estrus was confirmed in the present experiment by checking ewes each afternoon and evening with vasectomized rams after the breeding rams were removed.

Lambing data were collected from 293 ewes during late September and October. Lambs were born in two discrete groups as a result of progestogen-PMSG synchronization. Because fertility and ovulation rate may differ in response to first and second PMSG treatment, the ewes were divided into two lambing groups on the basis of their date of parturition. Data from seven ewes that died before lambing time were excluded from the analyses on fertility (percentage of ewes lambing and number of lambs born per ewe lambing).

The fertility data were analyzed by leastsquares analysis of data with unequal subclass numbers (Harvey, 1960); the model adjusted for the main effects of ram treatment, age of ewe, breed type of ewe and lambing group. Lambing group was excluded from the analysis on percentage of ewes lambing. Significant $F$ values were obtained for only ram treatment and lambing group. Other means were tested for significance by the Student's $t$ test (Steel and Torrie, 1960).

\section{Results}

Testes of Rams on Sbort-Days. Testes size of 
control and rams on short-days is reflected by their scrotal circumference (figure 1). Note that testes size was similar for both groups of rams in the beginning (time 0 ) and that testes size decreased during the early part of this study. Even though testes size continued to decrease $(\mathrm{P}<.01)$ in control rams throughout the study, testes of rams on short-days began to increase in size after the third week. From the third to the 10th week of treatment, average scrotal circumference increased $(\mathrm{P}<.01)$ from $34.7 \mathrm{~cm}$ to $37.8 \mathrm{~cm}$. As estimated from previous studies, this change reflects approximately a 40 to $50 \%$ increase in testicular mass.

Semen Quality of Sbort-Day Rams. Semen samples collected from all breeding rams during late winter were similar in quality to those that have been collected in other rams at that time of year (table 1). For control rams, the percentage of sperm with normal acrosomes (Johnson et al., 1976) continued to decrease $(\mathrm{P}<.01)$ during the first 9 weeks of the study. On the other hand, the percentage of motile sperm, live sperm and normal sperm did not change. Semen quality of rams on short-days at the beginning of the study was indeed similar to that seen in control rams; however, 9 weeks of exposure of rams to short daylengths neither increased nor decreased significantly the quality attributes of the ejaculates. Semen volume and total sperm per ejaculate were variable and not significantly affected by treatment.



Figure 1. Scrotal circumference of five Suffolk rams exposed to artificially shortened daylengths $(8 \mathrm{hr}$ light and $16 \mathrm{hr}$ darkness) during the nonbreeding season (o). Five control rams were maintained out-ofdoors under increasing daylengths $(\bullet)$.
Fertility of rams on Short-Days. Nearly all ewes showed estrus in response to progestogenPMSG treatment (table 2); however, only $67 \%$ of the ewes exposed to control rams and $89 \%$ of the ewes exposed to rams on short-days were actually mated. Most successful matings were obtained after the first PMSG injection. This conclusion was determined from the lambing dates of the ewes. Of the 150 ewes exposed to rams on short-days, 65 lambed in response to the first PMSG injection and another 34 lambed in response to the second PMSG injection. These values compare with 23 and 24 ewes lambing after exposure to control rams. When both lambing groups were combined, $67 \%$ of the ewes exposed to rams on short-days lambed; whereas, only $32 \%$ of the ewes exposed to control rams lambed (table 2). This difference in lambing percentage was highly significant $(\mathrm{P}<.01)$.

The number of lambs born to each ewe lambing tended $(\mathrm{P}<.10)$ to be higher for ewes mated to rams on short-days than those mated to control rams (table 2). A total of 202 lambs were born to matings with rams on short-days (1.35 lambs per ewe exposed), whereas, only 81 lambs were born to matings with control rams (.54 lambs per ewe exposed). Exposure of rams to short daylengths during the nonbreeding season did not affect the number of lambs born to each ewe lambing. However, it is of particular concern that lambing group affected the number of lambs born to each ewe. Ewes that conceived and lambed in response to the first PMSG injection averaged 2.16 \pm .11 lambs per ewe, but averaged only $1.51 \pm .14$ lambs per ewe after the second PMSG injection. Time of conception (relative to first or second PMSG), therefore, has a dramatic effect $(\mathrm{P}<.01)$ on the number of lambs born.

\section{Discussion}

Results of the present study confirm that short daylengths are beneficial to reproductive performance in rams and add substantially to our understanding of seasonal influences on ram fertility. As shown by previous investigators (Ortavant and Thibault, 1956; Alberio, 1976; Lincoln, 1976; Sanford et al., 1978; Schanbacher and Ford, 1979), rams exposed to short daylengths (e.g., $8 \mathrm{hr}$ light and $16 \mathrm{hr}$ darkness) during late winter and spring or after exposure to long daylengths, initiate a new sexual cycle characterized by increased serum 
TABLE 1. SEMEN QUALITY OF RAMS EXPOSED TO NATURAL OR ARTIFICIALLY SHORTENED DAYLENGTHS ${ }^{a}$

\begin{tabular}{|c|c|c|c|c|c|}
\hline \multirow[b]{2}{*}{ Treatment ${ }^{b}$} & \multirow[b]{2}{*}{$\begin{array}{l}\text { Time } \\
(w \mathrm{ks})\end{array}$} & \multicolumn{4}{|c|}{ Semen quality } \\
\hline & & $\begin{array}{l}\text { Progressive } \\
\text { motility }\end{array}$ & $\begin{array}{l}\text { Live } \\
\text { sperm }\end{array}$ & $\begin{array}{l}\text { Normal } \\
\text { acrosome }\end{array}$ & $\begin{array}{l}\text { Normal } \\
\text { sperm }^{\mathrm{d}}\end{array}$ \\
\hline $\begin{array}{l}\text { Control rams } \\
\text { (natural photoperiod) }\end{array}$ & $\begin{array}{l}0 \\
9\end{array}$ & $\begin{array}{l}57 \pm 7 \\
37 \pm 12\end{array}$ & $\begin{array}{l}57 \pm 5 \\
63 \pm 6\end{array}$ & $\begin{array}{l}77 \pm 5 \\
36 \pm 9 * *\end{array}$ & $\begin{array}{l}87 \pm 3 \\
92 \pm 2\end{array}$ \\
\hline $\begin{array}{l}\text { Rams on short-days } \\
\text { ( } 8: 16 \text { photoperiod) }\end{array}$ & $\begin{array}{l}0 \\
9\end{array}$ & $\begin{array}{l}52 \pm 11 \\
53 \pm 5\end{array}$ & $\begin{array}{l}63 \pm 5 \\
69 \pm 3\end{array}$ & $\begin{array}{l}81 \pm 4 \\
63 \pm 8\end{array}$ & $\begin{array}{l}86 \pm 9 \\
90 \pm 4\end{array}$ \\
\hline
\end{tabular}

${ }^{\mathrm{a}}$ Means \pm SEM for five animals.

${ }^{b}$ Control rams were maintained out-of-doors under natural lighting conditions of spring, whereas rams on short-days were maintained in a closed building under controlled lighting ( 8 hr light and 16 hr darkness).

${ }^{\mathrm{c}}$ Semen samples were collected and evaluated at the beginning of the study (time 0 ) and 9 weeks later just before breeding (time 9 ).

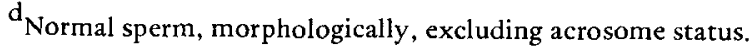

$* * \mathrm{P}<.01$. Significantly different from initial value (time 0 ).

concentrations of reproductive hormones, growth of the testes and increased sperm production. Combined with increased sexual behavior, rams on short-days can serve more estrous females and provide for maximum lamb production.

When rams are abruptly transferred from relatively long to short daylengths, a few weeks elapse before any gross changes are observed in the testes. As pointed out by Schanbacher and Ford (1979), a certain amount of time is required before an animal can respond to a change in photoperiod. Lincoln (1976) and Lincoln and Peet (1977) have carried out detailed studies on the temporal relationships between changes in photoperiods and changes in hormones in serum and have concluded that altered testicular function is dependent on a change in the secretion of gonadotropins. With this in mind, rams were exposed to short days for a total of 10 weeks so that any beneficial effects on sperm production might be taken advantage of at breeding time.

Although sperm output (Islam and Land,

TABLE 2. LAMBING DATA FOR EWES MATED TO RAMS WHICH WERE EXPOSED TO NATURAL OR ARTIFICIALLY SHORTENED DAYLENGTHS ${ }^{\mathfrak{a}}$

\begin{tabular}{|c|c|c|c|c|c|}
\hline Treatment ${ }^{b}$ & $\begin{array}{l}\text { Estrous } \\
\text { activity }\end{array}$ & $\begin{array}{l}\text { Mating } \\
\text { activity }\end{array}$ & $\begin{array}{l}\text { Lambing } \\
\text { rate }\end{array}$ & $\begin{array}{l}\text { No. lambs } \\
\text { born per } \\
\text { ewe lambing }\end{array}$ & $\begin{array}{l}\text { Actual } \\
\text { no. lambs } \\
\text { born }\end{array}$ \\
\hline $\begin{array}{l}\text { Control rams } \\
\text { (natural photoperiod) }\end{array}$ & $95.4 \pm 2.3$ & $66.7 \pm 18.1$ & $32.0 \pm .05$ & $1.72 \pm .14$ & 81 \\
\hline $\begin{array}{l}\text { Rams on short-days } \\
(8: 16 \text { photoperiod) }\end{array}$ & $98.0 \pm 1.3$ & $89.3 \pm 2.9$ & $67.2 \pm .05^{* *}$ & $1.95 \pm .12$ & 202 \\
\hline
\end{tabular}

\footnotetext{
${ }^{a}$ Means \pm SEM for five animals. Values for lambing rate and no. of lambs born per ewe lambing were derived from Least Squares Analyses.

${ }^{b}$ Control rams were maintained out-of-doors under natural lighting conditions of spring whereas rams on short-days were maintained in a closed building under controlled lighting ( $8 \mathrm{hr}$ light and 16 hr darkness for 91 days). Each ram was exposed to 30 progestogen-PMSG synchronized ewes. Data were collected and analyzed from two estrous cycles (21 day breeding period).
}

** $\mathrm{P}<.01$. Significantly different from control rams. 
1977) and sperm quality (Lunstra and Schanbacher, 1976) of rams are known to decrease during the spring and summer, only normal acrosome-bearing sperm appeared to be affected during this study. The percentage of progressively motile sperm tended to decrease during the study; however, this change was not significant. The fact that ejaculates from rams on short-days were similar in quality at the beginning and end of study suggests that the detrimental effects of spring were overcome by photoperiod treatment. When the sample-tosample variation in electro-ejaculated semen samples is considered, the effects of short photoperiods on semen quality cannot be determined with certainty. At best, it can be suggested that the normal decline in semen quality observed in the spring can be retarded by exposing the ram to short daylengths.

A peak in sexual activity is known to occur late in the breeding season (Schanbacher and Lunstra, 1976) and after several weeks of exposure to short photoperiods (Lincoln and Davidson, 1977). Similarly, the mating activity of rams exposed to short daylengths for 10 weeks was considerably greater than that of control rams during the nonbreeding season. Breeding performance by the rams on shortdays seemed comparable with that observed during the normal breeding season; all rams actively sought estrous females. On the other hand, considerable variation existed in control rams that were maintained under natural daylight conditions. Two of these rams were sexually aggressive in seeking the estrous females, but a third had reduced sexual interest and mated only about $50 \%$ of the available ewes. The other two rams showed very little interest in the estrous females and mated only a few ewes that were allotted to them. The diminished sexual interest of rams during the nonbreeding season has been observed in various breeds of rams being evaluated for libido with naturally cycling and (or) estrusinduced ovariectomized ewes (B. D. Schanbacher and D. D. Lunstra, unpublisbed data). Regarding the number of ewes that a single ram can breed successfully, it appears that 30 estrous-synchronized ewes present an appropriate challenge to the breeding ram during the nonbreeding season. A majority of ewes were bred, however, to rams on short-days. The libido of untreated rams, on the other hand, appears to be extremely low during the nonbreeding scason which makes them relatively incompetent as breeders. Sexual aggressiveness and mating behavior of breeding rams, particularly for out-of-season matings, should receive greater emphasis in the future.

As one might have expected, rams with increased testes size and improved mating behavior are likely to be more fertile. Rams on short-days in the present study not only mated more ewes than control rams, but produced 2.5 times more lambs than did control rams. Compared to other out-of-season matings in which the ewes have been synchronized with progestogen-PMSG treatment, a $67 \%$ lambing rate is quite acceptable. Those investigators who have reported greater than $\mathbf{5 0 \%}$ lambing rates to out-of-season matings have either used multiple-sire matings (Laster and Glimp, 1974), scheduled the breeding period at a time when the breeding animals are not necessarily in deep anestrus (Schanbacher, 1978), or used breeds of rams whose fertility may not be so dramatically affected by season (Christenson, 1976). Parker (1972) has shown that breed of ram contributes significantly to the fertility of single-sire matings during the nonbreeding season. Combined with the large ram variation observed in this study for lambing rate (0 to $81 \%$ ), the poor performance observed in the control rams of this study likely may be expected variation in libido and fertility for rams of the Suffolk breed. The percentage of ewes lambing in similarly designed studies with Suffolk rams at the US Meat Animal Research Center has been between 30 and $40 \%$ (unpublisbed data). Regardless of breed, it is postulated that the low conception rates in previous fertility studies with anestrous ewes can be attributed in part to poor fertility of the breeding ram.

Lamb production can be increased by affecting the number of ewes lambing as well as the number of lambs born to each ewe. Although the difference was statistically nonsignificant, rams on short-days sired more lambs per ewe lambing than did control rams. This finding suggests that a greater number of ova may have been fertilized by rams on short-days and (or) were maintained through the critical stages of development. Additional data are needed to confirm a positive effect of ram treatment on gamete fertilization or embryo survival.

In summary, it appears that average ram is a poor breeder during the nonbreeding season and that exposure to artificial photoperiods (specifically, short daylengths of $8 \mathrm{hr}$ of light) 
can induce the full sequence of events necessary to maximize breeding efficiency in the ram. Rams on short-days are sexually more active than control rams and, when mated to synchronized ewes, can result in increased lamb production.

\section{Literature Cited}

Alberio, R. 1976. Rolc de la photoperiode dans le developpement de la fonction de reproduction che $z$ l'agneau Ile-de-France, de la naissance a 21 mois. These Doc. 3c Cycle, Univ. Paris VI. 57 $\mathrm{pp}$.

Christenson, R. K. 1976. Effect of short-term progestogen treatment on induction of estrus and lambing in anestrous ewes. J. Anim. Sci. 43:795.

Dutt, K. H. 1960. Temperature and light as factors in reproduction among farm animals. J. Dairy Sci. 43:123. (Suppl.).

Harvey, W. R. 1960. Least-squares analysis of data with unequal subclass numbers. USD $\Lambda \Lambda \mathrm{RS}$ Bull. 20-8.

Islam, A. B. M. M. and R. B. J.and. 1977. Seasonal variation in testis diameter and sperm output of rams of breeds of different prolificacy. Anim. Prod. 25:311.

Johnson, L., W. E. Berndston and B. W. Pickett. 1976. An improved method for evaluating acrosomes of bovine spermatozoa. J. Anim. Sci. 42: 951.

Laster, D. B. and H. A. Cilimp. 1974. Influence of breed on response to exogenous hormones in estrous and anestrous ewes. J. Anim. Sci. 39: 1129.

Lees, J. 1965. Seasonal variation in the breeding activity of rams. Nature, London 207:221.

Lincoln, G. A. 1976. Secretion of 1.11 in rams exposed to two different photoperiods. J. Reprod. Fertil. 47:351.

I.incoln, G. $\Lambda$. and W. Davidson. 1977. The relationship between scxual and aggressive behaviour, and pituitary and testicular activity during the seasonal sexual cycle of rams, and the influence of photoperiod. J. Reprod. Fertil. 49:267.

Lincoln, G. A. and M. J. Peet. 1977. Photoperiodic control of gonadotrophin secretion in the ram: $A$ detailed study of the temporal changes in plasma levcls of follicle-stimulating hormone, lutcinizing hormone and testosterone following an abrupt switch from long to short days. J. Endocrinol. $74: 355$.

Lincoln, G. A., M. J. Peet and R. A. Cunningham. 1977. Seasonal and circadian changes in the episodic release of follicle-stimulating hormone, luteinizing hormone and testosterone in rams cxposed to artificial photoperiods. J. Endocrinol. $72: 337$.

Lunstra, D. D. and B. D. Schanbacher. 1976. Seasonal changes in reproductive traits of rams. J. Anim. Sci. 43:294 (Abstr.).

Marshall, F. 11. A. 1937. On the change over in the oestrous cycle in animals after transferance across the equator, with further obscrvations on the incidence of the breeding seasons and the factor controlling sexual periodicity. Proc. R. Soc. B. $122: 413$.

Ortavant, R. 1956. Action de la duree d'eclairement sur les processus spermatogenetiques che\% le belier. Compt. Rend. Soc. Biol. 150:471.

Ortavant, R. 1977. Photoperiodic regulation of reproduction in the sheep. Proc. Symp. Management of Reproduction in Sheep and Goats, Univ. of Wisconsin, Madison, July 1977, p. 58-71.

Ortavant, R., P. Mauleon and C. Thibault. 1964. Photoperiodic control of gonadal and hypophyseal activity in domestic animals. Ann. NY Acad. Sci. 117:157.

Ortavant, R. and C. Thibault. 1956. Influence de la duree quotidienne d'eclairement sur la spermatogenese du belier. P. 12-43. Proc. 2nd World Congress Fertil. and Steril.

Parker, C. F. 1972. Performance of ewe and ram brecds in a multiple lambing system. J. Anim. Sci. 35:181 (Abstr.).

Pelletier, J. and R. Ortavant. 1964. Influence de la duree d'eclairement sur le contenu hypophysaire en hormone gonadotropes liSH et ICSH chez le belier. Annls Biol. Anim. Biochim. Biophys. $4: 17$.

Pelleticr, J. and R. Ortavant. 1975. Photoperiodic control of LH release in the ram. I. Influence of increasing and decreasing light photoperiods. Acta Eindocrinol. 78:435.

Robinson, ' $T$. J. 1950. The control of fertility in sheep. Part I. Hormonal therapy in the induction of pregnancy in the anestrous ewc. J. Agr. Sci. Canb. 40:257.

Sanford, I.. M., D. B. Beaton, B. E. Howland and W. M. Palmer. 1978. Photoperiod-induced changes in I.II, FSH, prolactin and testosterone secretion in the ram. Can. J. Anim. Sci. 58:123.

Schanbacher, B. D. 1978. Iertility of rams chronically treated with gonadotropin releasing hormone during the nonbreeding scason. Biol. Reprod. $19: 661$.

Schanbacher, B. D. and J. J. Ford. 1979. Photoperiodic regulation of ovine spermatogenesis: Relationship to serum hormones. Biol. Reprod. 20: 719.

Schanbacher, B. D. and D. D. Lunstra. 1976. Seasonal changes in sexual activity and serum levels of LII and testosterone in Finnish Landrace and Suffolk rams. J. Anim. Sci. 43:644.

Steel, R. G. D. and J. H. Torric. 1960. Principles and Procedures of Statistics. McGraw-Ilill, New York.

Ycates, N. T. M. 1947. Influence of variation in length of day upon the breeding season of sheep. Nature, I.ondon 160:429. 